\title{
Morphological and Morphometric Attributes of Adult Indigenous Geese of Assam
}

\author{
Arundhati Phookan ${ }^{1 *}$, Bula Das ${ }^{1}$, Hanidul Hoque ${ }^{1}$, Ankita Gogoi ${ }^{2}$ and Momi Sarma ${ }^{1}$ \\ ${ }^{1}$ Department of Animal Genetics and Breeding, College of Veterinary Science, Assam \\ Agricultural University, Khanapara, Guwahati, Assam, India \\ ${ }^{2}$ Department of Animal Genetics and Breeding, Lakhimpur College of Veterinary Science, \\ Assam Agricultural University, Joyhing, North Lakhimpur, Assam, India \\ *Corresponding author
}

\section{A B S T R A C T}

\begin{tabular}{|c|}
\hline Keywords \\
\hline $\begin{array}{l}\text { Body weight, } \\
\text { indigenous } \\
\text { geese Assam, } \\
\text { morphometric } \\
\text { traits, } \\
\text { Morphology }\end{array}$ \\
\hline Article Info \\
\hline $\begin{array}{l}\text { Accepted: } \\
04 \text { October } 2020 \\
\text { Available Online: } \\
10 \text { November } 2020\end{array}$ \\
\hline
\end{tabular}

Introduction

Backyard poultry production is a proverbial activity amongst the rural livelihoods. It acts as remunerative business and holds an eminence over all other livestock enterprises. Although rural poultry husbandry cannot add to a large income, but it provides a skill to the poor farmers and give them a positive spirit in elevating their socio-economic status (Jensen

\begin{abstract}
The indigenous geese of Assam popularly known as 'Rajhanh' which means king of duck is a unique unexplored germplasm of Assam. Data of 53 adult indigenous geese of Assam were utilized for the present study. Data were collected by personal visits and interviews of farmers from the geese rearing areas. These geese are reared in the backyard in semi intensive system. The male female ratio usually found to be $1 \mathrm{M}$ : 3or4F. The plumage colour was found to be cinnamon (brownish), complete white and a mixture of cinnamon and white. The plumage pattern was observed to be solid and bordered. The bill colour was found to be black, orange and mixture of black and orange. Skin colour was observed to be white. Shank and feet appeared to be orange in colour. Eyes were found to be black, brown and grey in colour. In some birds knob was observed. The average body weight of adult indigenous geese was found to be $3.955 \pm 0.202 \mathrm{~kg}$. The average body length, body circumference, bill length, bill width, head length, head width, neck length, breast length, shank length, feet length, knob diameter and wing span were found to be $46.965 \pm 0.632$, $50.838 \pm 0.958,8.527 \pm 0.141,2.680 \pm 0.172,10.769 \pm 0.335,3.540 \pm 0.367,19.931 \pm 0.439$, $29.692 \pm 0.630,8.373 \pm 0.125,7.869 \pm 0.206,2.350 \pm 0.150$ and $110 \pm 4.421 \mathrm{~cm}$ respectively.
\end{abstract}

and Dolberg, 2003). Amongst the poultry, the geese farming is well acknowledged as there is scope for large profit using little or no inputs and their management and production can be solely led by women in the household. Geese are the waterfowls which belong to the Family Anatidae and the Genus Anser. Geese are among the fastest growing avian species with disease resistance quality and are commonly raised for meat, large edible eggs 
and valuable products such as feather and down (National Research Council, 1991). Geese are grass foragers and unlike chicken do not compete with humans for grains. Assam is fortunate to possess an indigenous germplasm of geese, locally being known as Rajhanh' which means the king of ducks. The geese rearing practice in the state dates back to ancient times. These geese are reared for ornamental purpose but are very good in guarding the premises. The geese are traditionally maintained on semi-range system in the backyard. They are provided with whole grain and then are allowed to move at their own for foraging at the nearby fields, swamps wetlands, ponds, rivers, etc. They are distributed throughout Assam. They are usually reared in a ratio of $1 \mathrm{M}$ : 3 or $4 \mathrm{~F}$. There lies opportunity for these geese to play a critical role in elevating the food and nutrition security of the poorest households and reducing the livelihood insecurity. It can be an effective tool for upliftment of poor. However, these germplasm is yet to be explored and are neglected to the extent that not even proper basic statistics are available. This study was carried out to generate baseline information on morphological and morphometric traits of the indigenous geese of Assam.

The data would help in recognition and registration of this germplasm, native to Assam. The documentation on their phenotypic features will further help in exploring and adopting scientific breeding strategy and management practices.

\section{Materials and Methods}

Data were collected from 53 adult indigenous geese (27 males and 26 females) of 1 year and above 1 year age from different areas of lower Assam on the basis of availability of geese under native field conditions. The age of geese was recorded on the basis of information provided by the farmers. Different morphological traits viz. plumage colour, plumage pattern, bill colour, skin colour, shank colour, feet colour and eye colour were recorded by personal visit to the study areas and observation of the geese on the spot. Different morphometric measurements viz. body length, body circumference, bill length, bill width, head length, head width, neck length, breast length, feet length, knob diameter and wing span were measured on spot by using measuring tape and slide calliper and expressed in $\mathrm{cm}$. The adult body weight was measured using a digital spring balance. Collected information was carefully checked, tabulated and analysed in the MS Excel for the descriptive statistics.

\section{Results and Discussion}

\section{Plumage colour}

The adult indigenous geese can be categorized into three groups based on plumage colour viz. cinnamon (brownish), complete white and a mixture of cinnamon and white. Similar finding was observed by Banerjee (2013) in indigenous geese of West Bengal; Islam et al., (2016) in indigenous geese of Bangladesh and Hamadani et al., (2020) in Kashmir Anz geese.

Juodka et al., (2012) conducted a study on Lithuanian Vishtines geese breed and observed that they had white plumage. Buckland and Guy (2002) reported that there are white, white grey, light grey, grey, brown grey, brown, fawn, buff and blue coloured geese across the world. Further, Saatci et al., (2009) reported that there are also yellow, pie bald and black coloured geese. The brown colour plumage in African, Brown Chinese geese (Wyeld et al., 1980) and Egyptian geese (Clauer and Skinner, 2007) corroborated with the cinnamon coloured geese found in Assam. 


\section{Plumage pattern}

The plumage pattern was found to be solid and bordered in indigenous geese of Assam.

Bill colour: The bill colour was found to be black, orange and mixture of black and orange. Juodka et al., (2012) observed orange coloured bill in Lithuanian Vishtines geese breed. Banerjee (2013) observed brown and orange coloured bill in indigenous geese of West Bengal. Islam et al., (2016) observed black and orange coloured bills in indigenous geese of Bangladesh. Hamadani et al.(2020) observed bill colour as black, yellow and intermediates. Different bill colours like orange, yellow, black, orange with black tip etc. also found in domestic geese (Buckland and Guy 2002; Echols 2015).

Skin colour: Skin colour was observed to be white. Similar finding was reported by Banerjee (2013), Islam et al., (2016) and Macharia et al., (2017) in indigenous geese of West Bengal, Bangladesh and Kenyan Geese respectively which were of white skin.

Shank and feet colour: Shank and feet appeared orange in colour. This finding found to be in accordance to the observation of Juodka et al., (2012) in Lithuanian Vishtines geese breed and Hamadani and Khan (2016) in Kashmir Anz geese. Indigenous geese of West Bengal, Bangladesh geese and Kenyan Geese had shown yellow shank as reported by Banerjee (2013), Islam et al., (2016) and Macharia et al., (2017) respectively.

Eye colour: Eyes were found to be black, brown and grey in colour. Eye colour in Kashmir Anz geese was found to be either grey or brown (Hamadani and Khan 2016). However, Juodka et al., (2012) conducted a study on Lithuanian Vishtines geese breed and observed that the geese had blue eyes. Islam et al., (2016) observed dark brown and blue coloured eyes in indigenous geese of Bangladesh.

Identification of gender: Sexual dimorphism on basis of plumage and eye colour, presence of curved tail feathers like in male ducks are not seen in indigenous geese of Assam. As per the farmer's observations and personal visits the gender can be identified by the voice which usually used to be higher pitched sound in males as compared to females. This fact can be supported by observations of Hamadani and Khan (2016), in Kashmir Anz geese.

Body weights: The average body weight of adult indigenous geese was found to $3.955 \pm 0.202 \mathrm{~kg}$. Comparable body weights in adult geese was reported by Banerjee (2003) in indigenous geese of West Bengal; Hamadani et al.(2014) in indigenous geese of Kashmir; Islam et al., (2016) in indigenous geese of Bangladesh and Macharia et al., (2017) in Kenyan Geese. A higher adult body weight compared to present finding were observed by Kumar et al., (2009) in geese from hilly terrain of Nilgiris, Juodka et al., (2012) in Lithuanian Vishtines Geese Breed and Sheikh (2013) in mature Embden geese.

Morphometric traits: The average body length, body circumference, bill length, bill width, head length, head width, neck length, breast length, shank length, feet length, knob diameter and wing span were found to be $46.965 \pm 0.632,50.838 \pm 0.958,8.527 \pm 0.141$, $2.680 \pm 0.172, \quad 10.769 \pm 0.335, \quad 3.540 \pm 0.367$, $19.931 \pm 0.439, \quad 29.692 \pm 0.630, \quad 8.373 \pm 0.125$, $7.869 \pm 0.206,2.350 \pm 0.150$ and $110 \pm 4.421$ $\mathrm{cm}$ respectively. Islam et al., (2016) observed a comparable bill length with present study however a higher body length, shank length and wing span was observed in mature indigenous geese of Bangladesh. A higher value for shank length of 10.78 and $10.16 \mathrm{~cm}$ in adult male and female Kenyan Geese was 
reported by Macharia et al., (2017). A comparable bill length, bill width, head width and knob diameter; however lower body circumference and a higher shank length, neck length, and wing span were observed in Kashmir Ansh geese (Hamadani et al., 2020). Higher shank length has been reported by Macharia et al., (2017) in Kenyan Geese where they found the shank length to be 10.78 and $10.16 \mathrm{~cm}$ respectively, in adult males and females.

In conclusions the indigenous geese of Assam are one of the few untapped poultry genetic resource which has a potentiality to provide supplementary income to the farmers. Further, baseline information obtained on morphology and morphometry of indigenous geese of Assam under their native field condition would be of great help in documentation and development of breed descriptors for registration, improvement and conservation of this germplasm.

\section{Acknowledgement}

The authors are thankful to the farmers whom they met and interviewed for the present study. The authors are highly grateful to the Assam Agricultural University for providing all the necessary facilities and support.

\section{References}

Banerjee, S. 2013. Morphological traits of duck and geese breeds of West Bengal India. Animal Genetic Resources. 52: $1-16$.

Buckland, R. and Guy, G. 2002. Goose production. Chapter 1: Origins and breeds of domestic geese. FAO Agriculture Department.

Clauer, P. J. and Skinner, J. L. 2007. Raising Waterfowl (A3311). Madison: Cooperative Extension Publishing.

Echols, M. S. 2015. "Anseriforme Husbandry and Management." In Backyard Poultry Medicine and Surgery, A Guide to Veterinary Practitioners, First ed. edited by C. B. Greenacre and T. Y. Morishita, 34-71, USA: Wiley Blackwell.

Hamadani, H. and Khan, A. A. 2016. "Morphological Characterization with Special Reference to Colour Variations in Domestic Geese (Anser Anser Domesticus)." Indian Journal of Animal Science 86 (4): 78.

Hamadani, H., Khan, A.A. and Banday, M.T. 2020. Kashmir Anz geese breed. World's poultry science journal. 76 (1): 144-153

Hamadani, H., Khan, A.A., Ganai, T.A.S., Banday, M.T. and Hamadani, A. 2014. Growth and production traits of domestic geese in local conditions of Kashmir, India. Indian Journal of Animal Science. 84 (5): 578-579.

Islam, M.F., Mia, M.M., Rahman, M.A. and Bhowmik, N. 2016. Morphometric, productive and reproductive traits of indigenous goose of Bangladesh. Animal Genetic Resources. 59: 37-45.

Jensen, H.A. and Dolberg F. 2003. A Conceptual Framework for using poultry as a Tool in Poverty Alleviation. A paper presented at the International Conference on Staying Poor: Chronic Poverty and Development Policy, IDPM, University of Manchester, April 7 to 9.

Juodka, R., Kiskiene, A., Skurdeniene, I., Ribikauskas, V. and Nainiene, R. 2012. Lithuanian Vishtines Goose Breed. World's Poultry Science Journal. 68: 51-62.

Kumar, R. A., Mathagowder, I. and Ragothaman,V. 2009. Growth and hatch performance of geese in hilly terrain of Nilgiris. Proceedings of the IV World Waterfowl Conference, Thrissur, India, 11-13 November.

Macharia, J. W., Mberu, M. N., Wamuyu, L., 
Imboma,T., Lichoti, J. K., Ngeiywa, K. J. and Ommeh, S.C. 2017. Phenotypic analysis of underutilized poultry species in Kenya. Livestock research for rural development. 29 (5).

National Research Council. 1991. Microlivestock: little-known small animals with a promising economic future. Washington, DC, National Academy Press.

Saatci, M., Tilki. M., Kaya, I. and Kirmizibayrak. T. 2009. "Effects of Fattening Length, Feather Colour and
Sex on Some Traits in Native Turkish Geese. II. Carcass Traits." Archiv Fur Geflugelkunde 73: 61-66.

Sheikh, F. 2013. Breeding and rearing of geese.

http://thepoultryguide.com/breedingand-rearing-of-geese/Accessed Februry 2014.

Wyeld, H. R., Wyeld, H., Groom, C. M., Hann, C. M. and Gibson, E. A. 1980. Geese, Ducks and Geese, Norwish: Stationary Office Books: 42-56.

\section{How to cite this article:}

Arundhati Phookan, Bula Das, Hanidul Hoque, Ankita Gogoi and Momi Sarma. 2020. Morphological and Morphometric Attributes of Adult Indigenous Geese of Assam. Int.J.Curr.Microbiol.App.Sci. 9(11): 3791-3795. doi: https://doi.org/10.20546/ijcmas.2020.911.455 